\title{
Pictures Worth the Proverbial Thousand Words: Multifaceted Loyalties As Expressed in Cartographic Mapping of Hungary, 1790-1848
}

\section{EVA BODNAR}

Depending on how the borders are drawn and interpreted and on the language(s) used to label territories and place names, maps of Central Europe can generate great debate. In present-day Hungary it is not uncommon to see maps of "Greater Hungary" on key chains, on backpacks, on necklaces, on the back of bus drivers' cabins, in the windows of antique stores and as bumper stickers on the bumpers of cars. These maps can have many meanings. They can indicate a person's political allegiance, a sense of national sentiment, an affinity for historical Hungary, solidarity with Hungarian-speakers living beyond the borders of the Hungarian republic, or disagreement with the 1920 Treaty of Trianon, Hungary's World War I agreement over the terms of peace. The treaty was a wound to the country which has never healed, and many Hungarians continue to resent the document which reduced Hungary to 93,000 square kilometers from 325,000 and left the nation with 7.6 million inhabitants instead of the 20.9 million the country possessed before 1914 (both of these statistics include the Kingdom of Croatia in the pre-war figures) (Lendvai 373).

Some observers have seen ominous overtones in these maps of "Greater Hungary." Colin Swatridge first came to Hungary in 1997 to teach English in Hungarian schools. In the book he wrote of his experiences, A Country Full of Aliens: A Briton in Hungary, he wondered at the ubiquitous persistence of the image of historic Hungary in map form in so many public places and spaces. Out of kindness to his colleagues he referred to Cluj-Napoca in Romania as Kolozsvár, its Hungarian name, but it was only a compromise on his part. As a Briton he was familiar with the legacy of British imperialism and thought there were distinct parallels at work here. Calling this city by its Hungarian name made him "complicit in a collective act of self-deception. It is just a little as if I still call Zimbabwe Rhodesia, and Sri Lanka Ceylon" (78). 
This essay is a study of maps and mapping enterprises that sketch the image of "Greater Hungary," or the historical Hungarian Kingdom. It will look at the same geographical space that conveys to some associations of nationalist political allegiances and sentiments, ethnic Magyar solidarity, resentment of Trianon, Hungarian imperialism, and what Swatridge viewed as present-day Hungarian self-deception. Instead of framing the discussion of maps of "Greater Hungary" in terms of these post-Trianon discourses on the subject, I look at the topic from another perspective: Roland Barthes' semiology, which I draw on to offer an alternative interpretation of what a map of the Kingdom of Hungary signified to those who produced the maps and to the public who read them.

Central here is Barthes' approach to semiology, which he understood as a "science that studied the way signs behave in social life." Barthes emphasized that the two most important qualities of sign systems were that they were essentially arbitrary, and that they were not mimetic, i.e. did not imitate reality, giving rise to the paradoxical situation whereby people derived constant meaning from signs which had no inherent meaning (Thody 39, 43). Barthes resolved the paradox of signs' receptivity by arguing that the designs people saw did not refer back to any fixed content, but rather to the activation of codes in a given reader's mind (Thody 118). Barthes developed these ideas in such works as "Eléments de sémiologie" ("Elements of Semiology") and System de la mode (The Fashion System).[1] While Barthes' examples are mostly from France in the 1960s and 1970s, and in relation primarily to language, as I show in this article, Barthes' system can also usefully be carried over into the realm of cartography, specifically, the mapping of the Kingdom of Hungary. Following Barthes' conception of semiology, a map of Hungary is a picture without any inherent meaning. The post-Trianon discourses associated with "Greater Hungary" listed at the beginning of the paper are arbitrary and can be replaced by others derived from other "codes of reference."

This paper will explore the codes of reference in maps of the Kingdom of Hungary which cartographers created between the years 1790 and 1848. These years encompass what Hungarian historians generally term the reformkor, or age of reform. The age of reform in Hungary is traditionally seen as having begun as a disagreement between feudal orders, namely the Hungarian nobility and Joseph II, their Habsburg king, over the king's powers of taxation, over the bureaucracy, military conscription and the language of administration in the Hungarian Kingdom. As the age of reform continued, feudal disagreements changed as civil society began to form and liberalism and 
nationalism entered political discourses. The term age of reform refers specifically to Hungarian politicians' attempts to transform Hungarian society through peaceful change, and to reconcile its feudal character with modern impulses.

It is informative to study maps of "Greater Hungary" between 1790 and 1848 because the Hungarian Kingdom was a component part of the Habsburg Empire during those years. The Habsburgs controlled European territories including Bohemia, Moravia, Upper Austria, Lower Austria, Tyrol, Styria, Transylvania, Carinthia, Carniola, and the military frontier bordering the Ottoman Empire, in addition to the Kingdom of Hungary. In 1804, after Napoleon's destruction of the Holy Roman Empire, the Habsburgs became emperors of Austria (Bérenger 130-1). Even after the Napoleonic wars ended, and the Congress of Vienna (re)established the borders of Central Europe, the Habsburgs retained their title as Austrian Emperors until 1918. The Kingdom of Hungary was thus a component part of an Austrian Empire which was in reality a Habsburg Empire made up of many regions. Like the empire of which it formed a part, Hungary was also a complex entity. It included territories now belonging to Slovakia, Croatia, Serbia, Romania and Ukraine, among other countries. In his groundbreaking 1842-1843 statistical work, Elek Fényes estimated in Magyarország statisztikája I-III (Hungarian Statistics I-III) that there were between 4.8 and 5.2 million ethnic Hungarians, between 2 and 2.2 million Romanians, 1.7 million Slovaks, 1.3 million Germans, 1.25 million Serbs, 0.9 million Croats and 0.44 million Ukrainians living in the Hungarian Kingdom (Für 220, 221, 228, 229 and 230).

Mapping the Hungarian Kingdom in the reform period was a challenge to mapmakers. Their pictures of "Greater Hungary," or the Hungarian Kingdom, had to take into account its various sub-components (kingdoms, regions with special privileges), as well as depict this conglomeration as a sub-section of the Austrian Empire. Following Barthes' idea that signs (in this case, maps) do not contain inherent meanings, this essay supports the notion that symbolic depictions on maps, choices made in their construction, and the motivations underlying their creation tell us as much, if not more about the people making the maps and their intended readers than about the actual pictorial representation. The actual picture involved constructions of Hungary in the reform era. Map creators did not have one single form of representation for the Hungarian Kingdom. The very same map designer, or company, could produce a map that respected the component political units of the Hungarian Kingdom, one that showed $a$ single country united under the Habsburg crown, and one that placed Hungary within the Austrian Empire. Map designers thus had 
complicated and ambiguous allegiances to the state (the component units of Hungary), to the nation (one Hungary united under the Habsburg crown) and to the Austrian Empire (the greater entity which encompassed Hungary).

After examining how the history of cartography has changed in recent scholarly writing, how historians have studied Hungary's geographic situation in English, German and Hungarian scholarly writing on Habsburg and Hungarian mapping from the mid-eighteenth and early nineteenth centuries, I will return to the argument of my paper. To substantiate my case that Hungarian cartographers held several layers of allegiances to state, national and imperial loyalties, I will look at four mapping projects in the reform era: 1) Demeter Görög's (1760-1833) maps; 2) Austrian and Hungarian depictions of Transylvania; 3) Ferenc Karacs' (1770-1838) Hungarian maps; and 4) ethnic mappings of the Kingdom of Hungary, touched on mainly in a work of Johann von Csaplovics (1780-1847). In between these sections I have included a short analysis of linguistic mapping and the magyarization of maps. The paper also contains an implicit argument that there was more similarity than difference in how cartographers based in the Austrian Empire and those working out of the Hungarian Kingdom drew Hungarian territory.

In fact, all such distinctions between cartographers based in the Austrian Empire and Hungarian cartographers must be approached with caution. Görög, Karacs and Csaplovics all created or reproduced images of the Kingdom of Hungary. They were also all Hungarian in the eighteenth-century meaning of the term, namely that they were born and lived in the Hungarian Kingdom. They were able to speak Magyar in addition to other Central European languages.[2] Görög, Karacs and Csaplovics belonged to the Hungarian nobility. Of these three men, only Karacs spent most of his life in Hungary proper. Görög's and Csaplovics's maps and writings centering on Hungary emanated largely from Vienna, the capital of the Austrian Empire. These men all supported the Hungarian nobility's attempt to transform Hungarian society during the reform period, at least to some extent. To borrow a term from postcolonial studies, perhaps it is better to view these intellectuals as existing in "contact zones" (Vienna for Görög and Csaplovics and Buda and Pest for Karacs) (Pratt 6 and 7 and Hannerz 556). Interaction in these multicultural environments nourished an interest for representations of Hungary which later became cartographic and literary projects sold as commodities in the Hungarian Kingdom. Whether or not the comparison with postcolonial studies is appropriate, the complexity of the ethnic background, linguistic capabilities, origin, and places of residence of these three 
cartographers and writers cannot be denied. The multilayered nature of their identities may serve as evidence to support why their images of Hungary contain loyalties to state, nation and empire that cannot easily be separated.

\section{CARTOGRAPHIC REVOLUTIONS:}

\section{NEW DIRECTIONS IN CARTOGRAPHIC WRITING}

Before launching into an examination of the multidimensional loyalties of cartographers and writers who produced visual and literary maps of Hungary in the reform period, I think it is important to take a look at recent developments in cartographic writing. After all, cartographic writing on Hungarian maps does not exist in a void. In recent years, the most important source for change in cartographic history has been the influence of theoretical writing. A series that played a significant role in creating this historiographical change was J.B Harley and David Woodward's The History of Cartography (1987, 1992 and 1994, later continued as Woodward and Lewis, 1998). The writings of Harley were particularly influential in this regard, and other works followed which similarly attempted to incorporate new, theoretical concepts into cartographic writing (Harley, 1983, 1989 and Harley and K. Zandvliet, 1992). Harley was largely inspired by the writings of Foucault. What is arguably Harley's most famous essay, "Maps, Knowledge and Power," reflects this ideological kinship in its title. In this essay, Harley states that: "[w]hether a map is produced under the banner of cartographic science - as most official maps have been - or whether it is an overt propaganda exercise, it cannot escape involvement in the processes by which power is deployed" (Harley 279). Such ideas became a source of debate among historians of cartography. One such debate occurred as scholars presented three important papers on theory and its use in cartography at the 16th International Conference on the History of Cartography, held September 11 15, 1995, in Vienna, Austria. These scholars argued that the inclusion of critical theory in writing on cartographic history would produce positive consequences for the entire discipline. They also argued that cartographic historians had for too long made assumptions in their analysis, which a better knowledge of critical theoretical concepts would help to expose. Specifically, Matthew H. Edney gave a paper putting forth the idea that maps were not empirical evidence but cultural products. Christian Jacob reminded his audience that maps made the invisible visible, that an empirical stance put the viewer inside the map but in actual fact the reader of a map had a vantage point which created a subjective picture. Finally, Catherine Delano 
Smith made a case for thinking of maps as not merely pictures, but as a "text," which was therefore open to being "read" in critical fashion (cf. Edney, Jacob, and Delano Smith). The conference's proceedings were subsequently published in Imago Mundi. Their ideas had a powerful effect in professional cartographic circles. Fairly quickly the inclusion of theory in cartographic historical writing became accepted to such a degree that by the time of his 1999 article on Renaissance mapping, Michael Wintle's first line informed his readership that: “(i)t is no longer controversial to maintain that maps are a form of discourse, that they represent viewpoints, opinions, aspirations and statements to their readers, who in turn interpret the data which maps present" (137).

\section{WHERE IS HUNGARY'S PLACE IN EUROPE?:}

\section{ENGLISH-LANGUAGE HISTORIOGRAPHY ON HUNGARIAN MAPS AND THE CONCERN WITH THE POWER POLITICS OF THE EAST/WEST EUROPEAN DIVIDE}

Ideas about power relationships expressed through mapping designs have not been overlooked in English-language writing dealing with Hungarian geography. Instead of studying individual Hungarian maps, the overall concern in this writing has focused more on the concept of borders. Specifically, the notion of "power blocks" between an "east" and a "west" has received repeated attention, and there has been great debate over which countries belong where at given points in time. In such writing the Austrian-Hungarian border often serves as a dominant geographical dividing line between Western and Eastern Europe. Or, in a related vein, writers have incorporated ideas about concepts of power, an "eastern" / "western" divide and separate cultural spheres. This historiography has examined the idea of a civilized region of Europe, "the west," which confronts the uncivilized "east." Hungary is usually seen as being part of the uncivilized "east" (Evans 497 and Wolff). The reasons for such a classification have varied from century to century. For example, in the late eighteenth and early nineteenth centuries, insufficient population and economic underdevelopment were often cited as markers differentiating Hungary from "civilized" Europe. Larry Wolff argues in Inventing Eastern Europe that these ideas were formed during the Enlightenment and were essential to its French philosophers, who needed a defined "uncivilized other" in order to be able to claim their own civility. The fact that such ideas have proved remarkably persistent may be gleaned not only from Wolff's book, but also from a general knowledge of twentieth-century European history. The post-1945 notion of 
the iron curtain, which divided Europe geographically into a democratic west and a communist east, largely retained the parameters between "civilized" and "uncivilized" Europe that had been established two centuries earlier.

\section{INCORPORATING HUNGARY INTO THE EMPIRE: GERMAN AND HUNGARIAN-LANGUAGE HISTORIOGRAPHY ON HABSBURG AND HUNGARIAN CARTOGRAPHIC ENTERPRISES}

The concern with a border between a "civilized" and "barbarian" Europe does not figure as prominently in non-English European writing on Austrian and Hungarian map production.[3] One reason for this discrepancy is that only wealthy people tended to have the resources to fund cartographic enterprises. The court, magnate status aristocrats, nobles or surveyors and engineers who carried out cartographic assignments for the army were the only ones who possessed the resources to create maps. Since cartographic production was (and greatly still is) limited to the wealthy, state authorities and to privileged military employees, historians and cartographers studying this subject have made a lengthy case for the "civility" of Austrian and Hungarian mapmaking, in the sense that it was limited to the elite (Vann). Not only was production limited to a few, but access to map products was also highly restricted. The people who were at that time considered the most important members of these feudal societies were the ones who could obtain the knowledge that maps contained. This situation in the Habsburg lands must be seen in contrast to other parts of Europe, such as Great Britain. There, cartographic products were more widely disseminated from the court to the populace, for example, in order to support a common project of British rule, in places such as India (Barrow).

Historians have devoted much attention to the mapping enterprises of the absolutist monarchs Maria Theresa and her son Joseph II (who reigned collectively from 1740 to 1790), partially because of the interconnections between power, empire and mapping. The ambition of these monarchs to depict their entire empire was a monumental task (Vann 163 and Jankó).[4] Their plans to map the empire functioned, of course, in tandem with imperial plans for administrative centralization, taxation of all social estates, and greater economic cohesion among territories. James Vann, who studied the mapping endeavors of the absolutist monarchs, considered the new direction in cartographic writing and concluded that: “(i)t is surely more than mere coincidence that at the very moment in which they began articulating the need for a powerful central government, the Habsburgs and 
their ministers turned to the concept of a comprehensive mapping scheme for the empire" (163). In other words, Habsburg mapping and the expansion of state control over their territories went hand in hand. The court's mapping of Hungary thus had connotations of achieving greater jurisdiction over Hungarian affairs, or of incorporating Hungary more tightly into the weave of the Habsburg-governed territories.

Two other aspects of Habsburg maps of Hungary add to the evidence of the connection between these maps of the Hungarian Kingdom and power. Firstly, an arm of the state, namely imperial military surveyors and engineers carried out or supervised the map work. It was the Corps of Engineers subordinated to the Headquarters of the Quartermaster General that was responsible for mapping enterprises. In 1764, a new department was created in the military for this purpose, the Department of Topography of the Military Archive (Vann 160-7). Other reorganizations followed, such as the creation of the Institute for Military Geography in 1839, which was directed by Joseph Scheda. Secondly, map products became state military secrets. The impetus that gave rise to imperial projects to map Hungary and other territories was in fact primarily military in nature. It was after the loss of Silesia to Frederick II of Prussia in the course of the Seven Years War, and the appearance of the second rival German military power, that Maria Theresa heeded the advice of Field Marshals Counts Leopold Daun and Moritz Lacy to initiate the comprehensive military survey of all the Habsburg lands.[5] The logic behind this endeavor was to ensure that if Habsburg court rulers made the decision to reengage in military combat anywhere on the territory they governed, they would have the necessary knowledge. For enlightened absolutist monarchs, maps possessed the potential to lessen the chance that the Hungarian Kingdom or another portion of the Empire would fall into the hands of a different European monarch through military defeat. For the court the fact that the maps of Hungary and other provinces were state secrets had an additional benefit. In the case of disputes between monarchs and the feudal estates, map knowledge gave the court a military advantage over the provinces and the unruly subjects who resided in them.

Recent specialist writing from Hungary has also seen power relations at work in the Habsburg mapping projects relating to the Hungarian Kingdom. For example, Irina Popova argues that during the second half of the reform era: "Austrian cartographers continued their work of incorporating Hungary into the Empire" (29). Also, Hungarian cartographic endeavors were a response to Habsburg mapping activities, namely: “to Klemens von Metternich's policy of gradual 
incorporation of Hungary into the Empire, to the Austrian maps, which showed Hungary as a Habsburg province, and to the attempts to create a new Austrian identity" (Popova 31). Popova also saw Hungarian cartographic projects as influenced by a variety of motives on the part of mapmakers. For these mapmakers used maps as: "a tool for constructing national identity" (i.e. a Magyar identity). At the same time, Hungarian mapmakers produced pictures which: "contained loyalty to the Habsburg Monarchy as an integral part" (19 and 20). In the end, though, Popova comes down on the side of Hungarian nationalism. By the 1840s, Hungarian cartography merged with the nationalism of segments of the Hungarian nobility and civil society, for "the aggrandizement of the Hungarian national movement had the cartographic layout of the national territory as one of its manifestations" (33). This essay seeks to discourage the idea that cartographers based in the Austrian Empire and those working out of the Kingdom of Hungary were easily distinguishable and pursued separate cartographic projects. It also suggests that Hungarian maps of the period reflected a balance of sentiments between state, national and imperial loyalties throughout the reform era. I hope the next sections will demonstrate these claims.

\section{DEMETER GÖRÖG, THE POST-JOSEPHIAN HUNGARIAN REACTION AND THE DOMAIN OF MAPS}

One person responsible for the creation of maps who was both a loyal imperial supporter and possessed a sense of national identity[6] was Demeter Görög (1760-1833), a Hungarian nobleman.[7] Based in Vienna, Görög's interest in cartography was so great that he convinced Prince Miklós Eszterházy, the father of one of his aristocratic students, to allow him to set up an institute for the production of maps in his Viennese palace, where engineers, engravers and drawers were paid to work (Nagy, 1977a, 407). This facility is known as the first Hungarian civilian mapmaking institute, and it is renowned not only for its maps but also for its employment and training of Hungarians with expertise in cartographic techniques (Papp-Váry 33).[8] Beginning in 1789 Görög also found time to edit the weekly periodical Hadi és más nevezetes történetek (Military and Other Stories of Note) along with his journalistic partner Sámuel Kerekes. From 1791 until 1803 it was published under the name Magyar Hirmondó (Hungarian News). After 1803 the journal ceased publication because of censorship.[9] Its initial sphere of coverage centered on the Austrian war against Turkey, but domestic and other international events also received attention. 
While Hadi és más nevezetes történetek never even vaguely expressed anti-Habsburg views, it was still part of the pro-Hungarian reaction against Joseph II in Hungary, dating back to the middle of his rule and continuing after his death (Haselsteiner, Lendvai 177-82). Hadi és más nevezetes történetek appeared only because it had the financial backing of three of Hungary's most influential aristocrats, who were at that time opposed to Habsburg policies in Hungary (such as Joseph II's refusal to be crowned king). These men were Ferenc Széchenyi, György Festetics, and Sámuel Teleki. Since they were prominent aristocrats and had the highest connections at court, support for such a venture was politically very sensitive. As a result, these men took steps to distance themselves from Görög's journal, and only supported it covertly. Only their secretaries, István Hajnóczy, Péter Takáts and László Szentjóbi Szabó, appeared at editorial meetings and acted as liaisons between Görög and Kerekes and their employers (Kókay 127). As the paper's political content was not antiimperial, its primary methodology to show its editorial sympathies was the fact that it was written in Magyar. According to the writers its aim was strongly national, to foster:

the enrichment of the Hungarian language, its standardization, its beautification, and in so doing the flowering of scientific ventures in greater strength, not only through our efforts, but through those of other worthy Patriots as well. We promise that we will use every means in our power to accomplish these aims, and will share them with the Homeland, as we have already done, without receiving payment or reward. Even the money that is left over from our costly work we wish to donate to support, in the best possible manner, academic projects in the language of our birth...[10]

These promises were all the more significant as Magyar language reform had not yet succeeded in producing a standardized language, and relatively few periodicals written in this language were in print.

The second aim of Hádi és más nevezetes történetek was pedagogical. According to Júlia Nagy, Görög's every plan, written thought, and action as a pedagogue, a journalist, an editor, a linguist, a writer on geographical topics, a map producer and an economist was motivated by a concern to raise the level of learning of his nation (Nagy, 1977a, 418). As might be expected from a Magyar-language paper, Görög's main reading public was the middle to lower nobility, the social group he thought was in need of Bildung. His journal satisfied the middle-nobility's thirst for news and interest in the course of the Turkish campaign, but was also read by writers, teachers, notaries, priests and students. Given the small publication numbers of the period, it is also safe to assume that it was read out by these same people 
to others at gatherings and assemblies, and so reached a wider public. Its Magyar emphasis may also have played a role in its respectable circulation numbers, with a total of 1300 paid subscribers (Kókay 127-8).

Görög's twin guiding philosophies - support for national development through the vehicle of the Magyar language and a desire to raise the level of learning of the middle/lower Hungarian nobility - combined with his interest in cartography through his journalistic activity. Hadi és más nevezetes történetek and Magyar Hirmondó both offered free maps to their subscribers in order to increase their geographical knowledge. In all 127 maps appeared in the pages of the papers (Nagy, 1977b, 211-2). Görög invested in the creation of these maps for his subscribers because of his passion for geography, mapping, and his hope that he would contribute to the spread of literacy and knowledge in the Hungarian Kingdom.

The gesture of producing 127 new maps for the journals was a very generous one, considering the cost of this enterprise. In the Magyar Hirmondó, Görög informed his readers that Count György Festetics alone had contributed over 2000 forints for the production of maps "in order to advance the commonweal." [11] These funds went toward engineer surveyors for the areas that were drawn according to new measurements and not merely copied from other, already existing maps, and toward the salaries of Görög and Kerekes' employees in the map institute, which amounted to 1200 forints annually. József Márton, Görög's friend, university professor and later editor of the Magyar Hirmondó, informed readers of these costs in a biography devoted to his patron (Márton 24).[12] Görög's institute produced all types of maps for the readership of his journal, including world maps and maps to enlighten his subscribers about the geographical areas where battles were being fought, such as his 1789 depiction of The Theatre Showing the Military Conflict between the Roman, Russian and Turkish Emperors (Nagy, 1977b, 215 and 220). But his most important maps were, arguably, those his institute produced depicting the Hungarian counties, which were subsequently republished as his Magyar Átlás (Hungarian Atlas). Görög was so committed to producing the Magyar Átlás that he left his position at the Hirmondó to devote himself to this work (Márton 22).

One reason for Görög's single-minded devotion to the project of the atlas was that maps of Hungarian counties were relatively rare, and their compilation in atlas form was even rarer. The engineer, surveyor and cartographer Sámuel Mikoviny had personally mapped Hungarian counties in the first half of the eighteenth century, but as a Major and Lieutenant-Colonel in the imperial army, and as an 
employee of the Viennese Treasury, his work was mostly classified material, although some of his county maps did find their way into print.[13] There was also a German atlas depicting Hungarian counties in existence, which was the work of János Mátyás Korabinszky. This atlas, for a German-speaking Hungarian public, contained maps in Latin, which was legally the official language of the country. Korabinszky had long occupied himself with geographical subjects relating to Hungary, and had in his Lexicon already alluded to the lack of proper material on the subject for those who were interested. He was compelled to create a Hungarian atlas because: “(a) general wish to possess an atlas of Hungary, and the difficulties relating to the appearance of one that are still present, made me determined to dare to develop an ideal map of this considerable empire" (Korabinszky 2).

Görög's Átlás made up for the insufficient number of atlases of Hungary detailing its county structure, and served his twin aims of broadening the use of the Magyar language in official publications and enlightening the Hungarian lesser nobility. Its title and the titles of all the maps in the atlas appear in both Magyar and Latin, but Magyar dominates over the Latin because each county map also contains a dedication to the person who helped finance its creation, and these are entirely in Magyar. For example, Temes (Plate 45) was dedicated to "the Honorable Count György Festetits, His Highness, for his decidedly progressive patriotic activity," while Árva (Plate 5) contained an inscription "to the Honorable Count Pál Szapáry, His Excellency, the Lord Lieutenant of Árva castle county (vármegye)." In all, the atlas contained fifty-three county and territory maps and seven maps detailing the military border districts. A Repertórium (Repertory) was also produced to correspond to the atlas, which listed all symbols and letters used on the legend for the maps in three languages: Magyar, Latin, and German. Great care was taken in the Repertorium in regard to place names. Görög respected the dominant ethnic groups in the hundreds of settlements detailed on the maps. Thus, the entry for Apaj noted that the Slovak equivalent for this place in Pozsony county was Opoj, and that Nagy-Szombat in the same county was Tyrnavia in Latin, Tyrnau in German and Trnawa in Slovak. The fact that Görög made such an effort to record and respect the multicultural and linguistic diversity of Hungarian settlements is particularly significant. For although his atlas was a landmark in terms of its use of Magyar, by not using exclusively Magyar names for places it walked a fine line and did not cross over into symbolic magyarization of the Kingdom of Hungary.

Görög walked a similar fine line in his own life. He maintained his connections at the highest levels of court until his retirement. At the 
same time, he engaged in patriotic practices in the service of the Hungarian Kingdom and its nobility that were not looked upon with royal and governmental favor, such as the aforementioned censorship of the Magyar Hirmondó when Görög assumed his new position as governor to aristocratic students around 1803 and also his strong support for the Hungarian national cause at the time of the reaction against Joseph II. Further, his house served as a gathering place after 1789 for young nobles eager to debate the ideas of freemasonry and the French Revolution. Even József Hajnóczy, who was later executed in 1795 for his left-wing political views as part of the Hungarian Jacobin conspiracy, was a frequent guest at his house.

Pál Mikó has examined the seeming incompatibility of Görög's measured Jacobin support and openness toward discussion of radical concepts combined with his strong Hungarian patriotism and imperial loyalty. She concludes that the imperial family had to have known about Görög's political leanings from secret police reports and that it was his exceptional learning, behavior, pedagogical abilities and trustworthiness that allowed him to keep his position at court (Mikó 94). Similarly, József Molnár saw him as at once a "stubborn Magyar, proud Hajduk noble and governor to the imperial family. At the same time he sought the favor of the king and sacrificed his fortune for the sake of works to benefit his homeland" (Molnár 4).[14] In other words, national, state and imperial loyalties were present both in aspects of Görög's life and in his work. Görög's publication of Hádi és más nevezetes történetek and Magyar Hirmondó gave people in the Kingdom of Hungary greater choice in selecting journals printed in Magyar, of which there were not very many. These journals also contained maps, financed by prominent Hungarian nobles and from Görög's own private wealth. The cartographic designs and the journals themselves were made in order to help spread the reach of the Hungarian language in Hungary, and to increase the level of learning of the lower nobility, minor officials and semi-literate Magyars. These aspects of Görög's life activity had national overtones. Simultaneous with his national leanings, Görög remained on good terms with his fellow nobles who constituted the Hungarian state. He was supportive of the Hungarian nobility's anti-Josephian stance, to the point of housing political debates in his living quarters that were tinged with Jacobin overtones. Somewhat extraordinarily, Görög was able to maintain his national and patriotic allegiances while retaining the best of imperial connections as a court governor. These loyalties may also be seen on a symbolic level in his cartographic activities, and most prominently in his Magyar Átlás. This significant cartographic work was printed predominantly in Hungarian (a national leaning), 
emphasized the county organization of the Kingdom of Hungary (the traditional state stronghold of the Hungarian nobility) and respected the authority of the Habsburgs (through its use of Latin, the officiallyrecognized language of the kingdom).

\section{SIEBENBÜRGEN OR ERDÉLY?: TERRITORIAL APPROPRIATION EXPRESSED IN MAPPING TRANSYLVANIA IN CARTOGRAPHIC EXAMPLES FROM THE AUSTRIAN EMPIRE AND THE KINGDOM OF HUNGARY}

Both maps of Hungary and atlases containing Hungarian depictions published in the Austrian Empire and in Hungary tended to reflect mapmakers' loyalties to nation, state and empire. In both maps and atlases division of the Kingdom into its component political areas dominated in terms of choice of representation. Either the division into political areas involved drawing the county organization of the country, as Görög had done, or mapmakers opted for a more common alternative: to delineate the component kingdoms, principalities, special districts and military border areas within the greater entity of the Kingdom of Hungary itself. Colors as well as border markings were used as important cartographic tools on maps showing these administrative divisions within the Kingdom of Hungary.[15]

Political conflicts between the Hungarian king (the Austrian emperor) and the Hungarian Estates over territorialization did not carry over significantly into the cartographic realm. Mapmakers working in the Austrian Empire were often willing to depict Hungary as a separate region somewhat apart from the rest of the imperial lands. In other words, they often drew a quasi-independent Hungarian Kingdom. Hungarian mapmakers were also just as likely to downplay national grievances by respecting existing borders. One excellent indicator of this principle was map designers' willingness to draw Transylvania as a separate principality governed from Vienna and not included in the Kingdom of Hungary. They placed Transylvania apart from Hungary even though its status as Hungarian territory had long been a subject of dispute between the Hungarian Estates and the king.[16] It must be added, though, that while both imperial map designers and those who worked more narrowly for the Hungarian market did respect the nature of Transylvania as a Habsburg province, the codes they utilized in these designs allowed for some ambiguity in terms of interpretation. If a person wanted to see Transylvania as part of the Empire or as belonging to the Hungarian state or nation, the very same map could achieve all of these purposes. 
Austrian cartographic examples, which made an effort to depict the political complexity of the Empire scrupulously, included the 1812 Allgemeiner Hand Atlas (General Pocket Atlas) by the Viennese firm Tranquillo Mollo (Konrad). Tranquillo Mollo was an Italian engraver, printer and publisher, who lived from 1767-1837. His Atlas mentioned above included a map of the "Austrian Monarchy," which took care to show its various regions as being distinctive entities (Konrad, 1812, "Charte der Österreichischen Monarchie" ("Map of the Austrian Monarchy"). Its drawings of Hungary reflected Croatia's and Slavonia's special status within the Kingdom of Hungary proper and the fact that they were politically united to the Hungarian crown. Even Transylvania received a similar treatment. Excluded from Hungary by its orange color (the Hungarian border had been drawn in yellow), it was simultaneously included by its presence. The title reflected the ambiguous nature of Transylvania's status in relation to Hungary by maintaining a balance between in- and exclusion. The map's title was simply "Charte von Ungarn und Siebenbürgen," or "Map of Hungary and Transylvania" (Konrad). The 1834 atlas put out by the Viennese firm Artaria u. Comp, Atlas der neuesten Geographie für Jedermann und jede Schulanstalt (Atlas Depicting the Most Recent Geography, For Every Person and all School Establishments) (Fried), shared many commonalities with its 1812 predecessor. The Atlas was so detailed that even Austria was drawn and delineated in component historical units (Fried, 1834, "Karte von Tirol, Steyermark, Illyrien" ("Map of Tirol, Styria, and Illyria")). Kingdoms that had had an existence prior to inclusion in the Empire were drawn in accordance with this principle, each receiving a fresh page that set them apart from the whole (Fried, 1834, Karte von Boehmen und der Markgrafschaft Maehren mit dem Antheile des Österreichischen herzogthumes Schliesen (Map of Bohemia and the Margravate of Moravia with Portions of the Austrian Duchy of Schliesen) and Fried, 1834, Karte von Ungarn und Galizien (Map of Hungary and Galicia")).

Cartographic depictions of Hungary by Hungarians did not differ significantly from the Austrian representations of the Kingdom. A Schedius and Blaschnek map may be taken as illustrative of this point. Lajos Schedius, a university professor, and Sámuel Blaschnek, a surveyor, produced an elaborate map of Hungary divided into nine plates, each of which was the size of a small table (Schedius and Blaschnek, 1833-1836). An elaborate painted cartouche displayed the crown of St. Stephen, below which was the coat of arms of Hungary in the center, with the coats of arms of Slavonia and Dalmatia to its left and Croatia and Transylvania to the right. Below the Hungarian names for these countries were German equivalents in slightly 
smaller script. Surrounding these crests, but outside of their enclosed circle, were six further ones depicting the countries of Galicia, Bosnia, Kun lands (special principalities within the Kingdom of Hungary), Lodomeria, Serbia and Bulgaria. The map itself used lines to set Transylvania, the Bukovina and Croatia apart from Hungary through emphasis, though of course their inclusion on the map also signified that they were simultaneously a part of the country. Division of Hungary into its constituent counties was naturally possible for a map of such a size, and it was done, but the dominant political division was into territories and kingdoms through the visual use of color (Schedius and Blaschnek, 1833-1836).

The 1814 map Karte von dem Königreiche Ungarn (Map of the Kingdom of Hungary) by Pest firm Industrie Comptoir used German as its communicative language, as it was intended for an educated Hungarian public. Produced slightly earlier than the Schedius map, it too maintained a balance between showing a greater Hungary and reminding the viewer of the political distinctiveness of kingdoms, territories, and special districts within the Hungarian monarchy, or of areas formerly aligned with it, such as Transylvania. Use of color accomplished this balance of inclusions and separations, just as Schedius and Blaschnek had done with their map. Hungary proper was divided into its counties, which were in turn labeled in German. Hungary itself was outlined in pink, and the divisions between the counties were in the same color. Croatia received a blush outline, and blue was reserved for Slavonia. Perhaps the choice of yellow purposely set Transylvania apart from the other, more darkly colored regions in order to undergird the fact that it was not a part of the Kingdom. The placement of Hungary, Croatia, Slavonia, Bukovina and Transylvania alongside one another implied visually that they were unified. In opposition to this unity, the mapmakers made the decision to divide Hungary proper into its constituent counties, while the other areas were left as solid geographical entities, with the implication that political jurisdictions did not entirely overlap.

Just as illustrations of Hungary did not differ significantly whether they were produced by firms from the Austrian Empire or the Kingdom of Hungary, there was also a considerable amount of convergence over representations of Transylvania. Imperial mapmakers showed a willingness to recall the memory of Transylvania's attachment to Hungary, even though it was officially governed as an Austrian province. Cartographers included this approach to drawing Transylvania in the map collection intended for use in Austrian schools, the 1813 Atlas der neuen Geographie zum Gebrauche der Schulen (Atlas Depicting New Geography for the Use of Schools). The atlas title 
and plate four both re-enforced the assumption of the pragmatic sanction, that the lands under the jurisdiction of the Austrian Emperor were part of one seamless whole. Its title reminded students that some provinces of the empire were imperial and others royal, but all these provinces belonged to the "Erbkaisertum Oesterreich" ("Austrian Hereditary Imperial Lands"). Plate four, a drawing of the hereditary imperial lands, showed the Kingdoms of Bohemia, Hungary, Croatia, Slavonia, Galicia, the Archduchy of Austria, Duchy of Styria, the Principality of Transylvania, the Margravate of Moravia and Austrian Silesia. All of these literary divisions into component parts were overruled by the use of color. By using only one yellow color to add life to the map, the effect was of a solid, unbroken territory.

With its imperial focus and its intent to instill this concept in school-age children, the Atlas der neuen Geographie displayed no greater tendency to show Transylvania as subordinate to the Austrian Empire than Hungarian cartography did. In fact, the illustration of Transylvania in this atlas was as part of the Hungarian lands. Plate nine-ten showcased the Kingdom of Hungary. Following convention, color divided the Kingdom into smaller regions: dark green for Hungary, red for Croatia, light mustard brown for Slavonia and pink for Transylvania. Different color codes divided Hungary, the Kingdoms of Croatia/Slavonia and the Principality of Transylvania, but the cartographers' decision to place these regions together, instead of opting for blank space, united them. The title also semi-fused these lands into one, for readers were asked to expect Ungarn samt den Vereinigten Ländern und Siebenbürgen (Hungary Together With the United Lands and Transylvania, 1813).

Austrian map production thus showed openness towards the (partial) inclusion of Transylvania as a portion of Hungary. Mapmakers working in Hungary were just as inclined to recognize the (quasi) separate status of the former Hungarian province. The 1834 map Erdély ország közönséges földképe (General Map of the Country of Translyvania) (Karacs) clearly broke with the prevalent practice of placing Transylvania beside Hungary by making it the sole focus of representation. This technique strongly underlined Transylvania's independence from the Hungarian Kingdom. The cartographer drew Transylvania as an independent principality, but the codes on the map undermined the region's total political sovereignty from Hungary. The designer of Erdély ország közönséges földképe chose Magyar as the language of the map, which underscored the connection of the principality to Hungary itself. The designer also stated that his map had a national purpose to teach Hungarian boys, whether they lived 
in the Kingdom itself or in Transylvania, about this piece of territory, which they would be conditioned to study in Magyar.

Another Hungarian-produced map that explicitly reminded its viewers of Transylvania's simultaneous in- and exclusion from the Kingdom of Hungary was a second Schedius map, this time printed in German. Karte des Königreichs Ungarn seiner Nebenländer und Siebenbürgen (Map of the Kingdom of Hungary, Its Neighboring Lands and Those of Transylvania, 1838) had a precise legend detailing the country organization of the territory depicted. Here rivers, cities and even land height were the main geographical components of the map instead of having the more traditional political/territorial division as the primary organizing principle. The overall effect, however, produced meaning with political overtones. Hungarian and Transylvanian territories appeared more connected than they actually were simply because solid masses of unbroken territory were not separated by borders. Other elements of the map worked against the unity created by drawing continuous terrain. The title clearly underscored that separate geographic entities were together on one map. As well, the mapmakers' decision to use the German language connected both Hungary and Transylvania to the Austrian Empire and reminded viewers that an educated Hungarian public, of whatever nationality, had the obligation to be able to read a map in German.[17]

Cartographers based in the Austrian Empire and the Hungarian Kingdom did not depict Hungary, Transylvania, border regions or the surrounding areas in a markedly different manner. Political representation was the most common form for their images. Maps contained several layers of meaning that could connect Hungary or former regions of the Kingdom, such as the Principality of Transylvania, to the Austrian Empire. At the same time, mapmakers often paid attention to the semi-independent nature of the Kingdom in contrast to the lands under stronger Austrian jurisdiction, as well as to the semi-sovereignty of the constituent parts that made up the Hungarian monarchy. The maintenance of ambiguity in the mapping of Transylvania probably served the interests of cartographers. For if a person wanted to see Transylvania as a portion of the Kingdom of Hungary, there was enough symbolism for her to do so. Conversely, if a reader in the Austrian Empire wished to see Transylvania's status as a Habsburg province confirmed, maps reinforced this political reality as well. 


\section{LINGUISTIC MAPPING: \\ THE MAGYARIZATION OF HUNGARIAN MAPS}

Mapping firms working primarily in the Austrian Empire or in the Kingdom of Hungary engaged in no real 'dispute' in the cartographic realm over how Hungary should be drawn, or over Transylvania's 'connection' to Hungary and/or the Habsburg territories. The shift that took place in this period in conjunction with mapping Hungary did not center on border disputes but on linguistic parameters. Over the course of the reform period, cartographers began to draw maps of Hungary using the framework of the Magyar language, instead of German or the more common, official, legal language of Latin. The shift to Magyar was part of the liberal-nationalism of the Hungarian reform period. Leading politicians such as Ferenc Deák[18] campaigned for such liberal goals as the extension of the rights of the Hungarian constitution to include all non-noble inhabitants of the Kingdom. At the same time, national ideas came more to the fore. In parliament there were increasing demands for upper-level administration to be in Magyar and for tertiary schooling to be in this language as well.[19] The most strident goal was the movement to make Magyar the official language of the multinational country. This movement gained a great victory with the enactment of the 1844 law, which made Magyar the official language of the land in the Kingdom of Hungary. The gradual magyarization of maps paralleled the general campaign to expand the scope of the Magyar language in Hungary.

Cartographic experts had the power to choose whether or not to magyarize a map of the Kingdom of Hungary and also to determine how thoroughly the pictorial and linguistic magyarization should dominate the work. Some chose to favor Magyar, while others deemed it more appropriate to err on the side of caution. For example, in a reversion to tradition, the Viennese firm Artaria et Comp decided to issue its new map of the Hungarian component lands (but not Transylvania!), in traditional Latin in 1801. Mappa novissima regnorum Hungariae, Croatiae, Sclavoniae (New Map of the Kingdom of Hungary, Croatia, Slavonia) did not have Latin and Magyar alongside one another (as Görög's Magyar Átlás did), or Latin and German side-by-side (Korabinszky's choice of representation for his Atlas Regni Hungariae portatilis (Portable Atlas of the Hungarian Kingdom). The title, the language of the map, and the names of the counties (in the case of this map fifty-nine in number) were all in Latin. Also in a nod to tradition, the divisions of the counties into the sub-components of Western Danubian counties/ Eastern Danubian counties, Western Tisza counties/ Eastern Tisza counties and the Counties of Slavonia and 
Croatia were similar to legend categorizations and spatial divisions that could be found on numerous other maps (Szántai 503).[20] The map had a nostalgic quality with its representation of the Hungarian Kingdom as a land of peace and plenty, which was not entirely accurate considering that the Napoleonic wars were raging in many zones on the continent and the economic havoc caused by these wars did not leave Hungary unscathed. Despite this fact, the map artist did not see Hungary as being particularly endangered. He chose to represent the land twice: once as a drawing and a second time pictorially in the form of a cornucopia, spilling over with fruits and grain, grazing cattle and animals killed in hunting.

One reason that cartographic firms such as Artaria et Comp did not choose to switch to Magyar had nothing to do with their political loyalties or personal preferences. Simply put, Magyar was still in the process of being standardized. Language reformer, writer and critic Ferenc Kazinczy (1759-1831) accomplished much in terms of reforming Magyar in the late eighteenth and early nineteenth centuries. He proposed changes in terms of grammar and the formation of new words, but it took generations before those who used the language agreed on terminology and sentence construction. Other areas in Europe also experienced movements to reform the language, such as the German-speaking portions of the Holy Roman Empire. The qualities which made the Magyar-language reform movement distinctive from its German counterparts were the relatively large number of new word coinages that had to be created. Adding to the complexity, writers could decide to adapt their words from such languages as old Magyar, Latin or German. Each person who produced an article, wrote a book, or created a map could, and often did, put forward new vocabulary to denote particular concepts. The absence of one version of the language which was used by all created a situation where map producers who chose Magyar as their medium for communication had to be amateur linguists as well as cartographers. Vocabulary for place names, the grammar connected to the terms, and their orthography varied from person to person and from map to map.

To give an example from the realm of linguistic mapping, Hungarians who wanted to coin a name for the United States of America in Magyar faced a perplexing challenge. Different maps by individual cartographers variously labeled America as the "Az egyesült Szabad Társaságok" ("United Free Associations," 1804), the "A' Szövetséges Országok" ("Confederated Countries," 1819), the "Egyesült Tartományok" ("United Territories," 1838) and the "Észak Amerikai egyesült álladalmak" ("North American United Republican States," 1843). Since there was no standard Magyar name, the personality, 
personal preference and linguistic creativity of the cartographer determined the form of the name of the country. The aspect of America that individual map designers most admired came to the fore. Some cartographers admired America's cohesion (united), some the fact that politicians brought the states together by mutual peaceful agreement (confederated) and some that Americans had a non-monarchical, advanced form of government (republican). Hungarian maps designers began to agree on the term "Egyesült Államok" ("United States") as the appropriate term for the country only circa 1874 (Danku 16 and 17). Challenges relating to Hungarian place names in the Hungarian Kingdom were just as problematic as deciding what to label the new republic in North America. Maps provide an excellent case study of the reform of the Magyar language, which took decades longer to accomplish than much of the historiography on the subject assumes.

Despite the difficulties connected with terminology, or out of a desire to overcome these obstacles, cartographers increasingly produced maps and atlases exclusively in Magyar. These maps were designed to appeal to a public who wanted or needed Magyar maps, because the fact that they were written in the "national language" often was a selling point in their favor, as their titles indicated. The 1804 Oskolai magyar új atlas (New Hungarian School Atlas) was an example of one such work. The atlas was the product of student engraving at the Debrecen Calvinist Collegium (Erôs, Pap and Pethes). It reached such a high standard that the work could be published as a professional atlas, due to help from people such as Professor Ésaiás Budai (1766-1841). A Latin atlas was the basis for the work, and students translated and invented equivalent Magyar terminology in order to create linguistic approximations for standardised Latin terminology (Danku 7). In contrast to Görög's Magyar-language map productions, the Oskolai magyar új atlas depicted more than Hungarian counties in Magyar. It is only on Plate Six that Hungary appeared, but it was preceded by five plates showing "A Drawing of the Five Regions of the World," "Europe," "Asia," "Africa," and "America." The atlas showcased how Magyar was becoming more functional in the sense that it had by then developed terminology for describing abstract (in this case geographical) concepts far beyond the physical borders of the Hungarian Kingdom. Increasingly it became possible to see the Kingdom of Hungary, and the entire world, though a Magyar lens. Although Hungarian cartography did increasingly accommodate national impulses in maps by using Magyar as its primary communicative language, the next section makes clear that there were clear limits to magyarization and Hungarian mapping practices. 


\section{FERENC KARACS AND THE EXTENT AND LIMITS OF MAGYAR MAPPING IN THE REFORM PERIOD}

One reform period cartographer who did much to further the magyarization of maps was Ferenc Karacs (1770-1838). Born in Püspökladány, he too was schooled at the Debrecen Calvinist Collegium, the centre for cartographic excellence already mentioned. There, he learned his outstanding skill in copper engraving techniques (Kálvinfalvai 3 and 28). His skill surpassed those of many other students, for he was able to engrave the entire Lord's Prayer in readable format on one square centimeter of space. Over the course of his lifetime he shifted his ambition from engraving maps for the benefit of other mapmakers[21] to being both the engraver and publisher of his own cartographic products. By the end of his life, he had engraved and published over 100 maps (Horvath 139).

Arguably, Karacs' most famous professional works were his school wall map (Karacs 1813), produced for the Calvinist community in Pest, and his Európa Magyar Atlása (European Hungarian Atlas) (Karacs, 1834-1838). The first map was novel for having 8000 place names, a feat that was rare even on the most detailed maps (Kálvinfalvai 30). The map's use of Magyar for the entire Kingdom was symbolic, transforming a multinational country that was part of the Austrian Empire into "a linguistically uniform and politically independent country" (Popova 30).

Still, it would be wrong to conclude that because Karacs produced maps in the "national Hungarian language," as his advertisements claimed, that nationalization of the Hungarian Kingdom, magyarization, or even republicanism dominated his thinking. Karacs may have wanted to give his Magyar-speaking, educated, map-reading public the opportunity geographically to understand the world in this language, but there were limitations to his national sentiment. Being from the middle nobility, Karacs had limited financial means to fund a venture as expensive as cartography. These limited finances entailed compromises and limited the degree to which Karacs carried out (or wished to carry out) any "national agenda" in his cartographic works.

Karacs' maps first saw the light of day in István Kultsár's Hazai és külföldi tudósitások (Domestic and Foreign Reports)[22] and were later published in Atlas form in Európa Magyar Atlása. Hazai és külföldi tudósitások distributed the maps as inserts from 1821 until 1834. Twenty-one of Karacs' planned twenty-four maps were thus put before the public (Ecsedi 97 and 98). Their funding came from such prominent places as the Hungarian Vice-Regal Council (Popova 31) and influential and wealthy patrons, as his dedications beneath each 
map in the Európa Magyar Atlása reveal. For example, his first plate, showing "A Picture of the Two Halves of the World" was dedicated in lengthy manner to Count Adám Reviczky of the Hungarian Treasury. Plate Six, a "Map of England, Scotland and Ireland," rewarded the financial contribution of Prince Pál Eszterházy, the "eternal and true" Lord Lieutenant of Sopron County (Karacs, 1834-1838). Given these parameters, but also probably out of genuine conviction, a man who had produced a map of Hungary displaying the Magyar country as a politically independent entity (the school wall map) could also produce a map of the exact same spatial realm as a component part of the Austrian Empire. Plate fourteen of the atlas represents "The Austrian Empire and the Italian Territories which Belong to this House." This map clearly portrays the Kingdom of Hungary as one part of a conglomeration that included Austria, the Tyrol, Styria, Illyria (with Carinthia and Carniola), Dalmatia, the Kingdom of Lombardy-Venice, Czech Country, Galizia, Hungary (with the countries of Croatia and Slavonia), Transylvania and the Military Districts (Karacs, 1834-1838).

For Karacs sentiments of state loyalty to the Kingdom of Hungary and broader imperial support in favor of a greater Austrian Empire alternated with various cartographic examples of his work. It is often impossible to tell where one loyalty ended and another began.

Alongside these ideas were nationalistic sentiments because there was a pronounced effort to produce the maps in Magyar as opposed to German or Latin. Yet, his magyarization efforts had clear limits. The fact that Karacs and other leading Hungarian cartographers produced maps that increasingly favored Magyar as a communicative tool, and wished their audience likewise to be cartographically educated in Magyar, did not necessarily imply at this point that they were symbolically appropriating the Kingdom of Hungary for Magyars, to the exclusion of other nationalities.

\section{ETHNIC MAPPING: DEPICTING THE CONSTITUENT NATIONALITIES OF THE KINGDOM OF HUNGARY}

Thus the magyarization of maps did not necessarily imply a desire to symbolically magyarize the Hungarian Kingdom completely. Instead, these maps reflected mapmakers' complex patterns of loyalty to imperial, state and national political entities. One final piece of evidence to support the idea that maps of the period contained multiple layers of symbolic political allegiances is another category of map, which I have not yet mentioned. Almost all of the maps which were the basis for this essay depicted the political organization of the country. These maps displayed the Austrian Empire, the constituent kingdoms and 
territories within the Kingdom of Hungary itself, or the complicated county organization of Hungary. Maps depicting the ethnic distribution of peoples within Hungary were largely absent. Such maps were in circulation but in small numbers.

A journalist named Johann von Csaplovics (1780-1847) included an ethnic map of the Hungarian Kingdom in his Gemälde von Ungarn (Portrait of Hungary). Csaplovics (also known as Ján Čsaplovič in Slovak and János Csaplovics in Hungarian) was a noble-born lawyer from Hont county in Hungary, who after 1813 made a living working for the princely Schönborn family, administering their estates in Munkács from Vienna. He also wrote extensively in the press for such publications as Hirnök Tárca (News Portfolio) and Századunk (Our Century), and published a series of books. Csaplovics held some liberal beliefs: his articles often dealt with the topic of freedom of the press, and he saw the Hungarian nobility's exemption from taxes as a negative aspect of political life. At the same time, his beliefs had strong conservative strokes because he thought some measure of enforced censorship of the press was necessary (Kokay). Csaplovics' book Gemälde von Ungarn (Paintings of Hungary) was an early work of statistics in the sense that it described the geographical, cultural, and political nature of a particular topic, in this case Hungary. His map in this text showed through the use of color where majorities of Slovak, German, Ruthenian, Romanian, Croatian and Serbian settlements were located in the Hungarian monarchy. It was a rather unsophisticated map, using the standard of the other maps listed in this essay as a guide, but this aspect of the design may be attributed to more limited financial resources on his part than those available to the other map producers and firms that have already been mentioned.

Csaplovics probably included an ethnic map of Hungary in his Gemälde von Ungarn because he needed a different framework of reference to depict the Kingdom than the political maps that Hungarian map creators and those working in other parts of the Austrian Empire overwhelmingly preferred. Like Görög and Karacs, Csaplovics showed a sense of respect for the Austrian Empire, which, as a legal administrator to a prominent aristocratic family based in Vienna, was his main source of earning money. Simultaneously, Csaplovics felt a sense of loyalty to the Kingdom of Hungary, for it alone was the topic of his book, not the Austrian Empire itself. In his case, though, there was a special sense of loyalty towards the Slovak-speaking portions of Upper Hungary. So strong was this sense of patriotism in Csaplovics's writings that by the 1840s he spoke out against the magyarization of the Hungarian Kingdom (Kokay). Csaplovics possessed a form of state patriotism that did not mesh with that of Görög and 
Karacs, who both felt comfortable drawing the political boundaries of the Hungarian Kingdom. Csaplovics subscribed to a different form of loyalty to the Kingdom of Hungary, one which placed greater weight on his Slovak origin. This loyalty found expression with his inclusion of the ethnic map in his Gemälde von Ungarn. Voices such as his were not silenced in the Hungarian reform period. They were simply a minority in comparison to others who supported the liberalizing project of the Hungarian nobility more wholeheartedly, including its campaign to further the scope of the Magyar language. In the domain of maps, mapmakers often chose to depict this state of affairs with political representations of the Hungarian Kingdom instead of ethnic ones. Hence there were relatively fewer ethnic mappings of Hungary, but they were not incompatible with Hungarian patriotism, for Csaplovics was a Hungarian nobleman, who wrote about his country in German, Magyar and Slovak. His ethnic representation of the Hungarian Kingdom was another form of symbolic political allegiance to state and nation than those of Görög and Karacs' pictures, but in the reform period these various viewpoints could exist reasonably well side by side.

Greater insight into Csaplovics's views can be gleaned from reading Gemälde von Ungarn, which contains both an ethnic map of Hungary and a literary picture of the same geographical space. Csaplovics expressed concern that the German language was declining in its scope within Hungary's borders. It pained him to see that "the number of so-called native German-speakers is decreasing day by day because they either magyarize or slovakize or ruthenize based on whether they neighbor or cohabit alongside this or that group of people" (Csaplovics 222). This process was occurring despite the considerable state advantages German held due to its importance in the Austrian Empire and as the second quasi-official language in the Hungarian Kingdom. He noticed that in Hungary "no other language is fortunate enough to claim the many powerful ways and methods of support given to this language and to the extension of its use" (Csaplovics 220). Among those who were born in Slovak regions of the Kingdom, Slovak did not have the cachet in Hungary which other languages, such as German, were able to claim. Csaplovics lamented how "no people in Hungary is as indifferent to their mother tongue as are the Slovaks. Learned people are ashamed to speak in Slovak to one another and always use the Latin or German language" (Caplovics 220). At least Slovaks had the saving grace that they were quite pleased to correct the linguistic errors people made when attempting to speak the language. Hungarians who spoke Magyar and ethnic Germans who did the same were not as kind. For, according to 
Csaplovics, "the Magyars enjoy making fun of foreigners who speak Hungarian incorrectly, and the Germans follow suit" (Csaplovics 223). All of these pithy observations created a verbal ethnic map of a country demographically in flux, beyond the scope of what any mere pictorial map could depict.

Csaplovics' ethnic maps, both traditional and literary, continued to be rarer in Hungary than their political counterparts for years to come. One need only look at English travel writer John Paget (1808-1892) and his Hungary and Transylvania with Remarks on their Condition, Social, Political and Economical. Paget was not a cartographer but, like Csaplovics, he produced a portrait of the Kingdom of Hungary. Ten years after Csaplovics' book appeared, Paget needed an ethnic map to help his English readers (including those in the Kingdom of Hungary) understand the Hungary and Transylvania his writing described. For his book he had to use the Csaplovics map because it was the best one in existence (Paget xii). The map was needed not only because he assumed that his English-reading public outside of Central Europe would largely be ignorant of the relationship between ethnic groups and geographic space in the Kingdom of Hungary. By then Paget thought ethnic issues in the Hungarian Kingdom were becoming more important, and he overcame his reservations about Csaplovics's map which he deemed "not strictly accurate, yet it [was] a sufficiently near approximation to the truth" in order to illuminate "one of the greatest national questions in Hungary - the division of its population into several distinct races, for the most part inhabiting different districts" (Paget xii).

In the Hungarian reform period political maps were largely sufficient to express cartographers' loyalties to state, nation and Empire. The appearance of ethnic maps on the scene began to unsettle the equilibrium which cartographers held to these three associational allegiances, which did not demand ethnic exclusivity, whether Magyar or otherwise, on the part of the mapmaker. It is perhaps not surprising, given the course of subsequent Hungarian history, that in years to come ethnic maps became all the rage.

\section{NOTES}

[1] All translations in this essay are by the paper's author.

[2] From now on I will use the term Hungarian to refer to someone who was an inhabitant of the Hungarian Kingdom. In contrast, I use the word Magyar to imply an ethnic awareness of Hungarian background and the beginnings of a national agenda. 
[3] See for example Szántai's book, which places weight on the relatively long tradition and large number of Hungarian maps and not on Hungary's place in "civilized" Europe (Szántai 1996).

[4] The first survey of the empire began in 1764 , took twenty-three years to complete, and yielded 5400 maps. Joseph II mapped Hungary on several levels simultaneously between 1786-1790, producing a census of the population of Hungary and Transylvania (1784-1787), and an eighteenth-century equivalent of GNP analysis known as the "land survey." The land survey was arguably the most famous mapping attempt of the Habsburg rulers in Hungary because it evoked such opposition on the part of the Hungarian nobles, who objected so greatly to the taxation that it had to be abandoned before completion (Dickson 611, 612 and 629). Francis I commissioned another survey of the empire to rectify the lack of common surveying techniques used in the previous undertakings. Begun in 1806, it was not completed until 1869, an astonishing sixty-three years later (Papp-Váry 52).

[5] Interestingly, Hungary was surveyed from the outskirts of the kingdom toward the centre, perhaps reflecting areas of military vulnerability. Máramaros was first to be surveyed between 1766 and 1768 by Lieutenants Hofmann and Pauletti under the direction of Major Sterling. Transylvania, officially under Habsburg control, followed with its survey between 1769 and 1773 under the direction of Colonel von Fabris. The Banat was surveyed between 1769 and 1772 under Colonel Elmpt. Upper Hungary received considerable attention, as it was surveyed in two parts. The first two surveys were both between 1770-1772 under Lieutenant Colonel von Motzel (Trencsén, Turóc, and Árva counties and Árva, Liptó, Szepes, Sáros, Zemplén, Ung and Bereg counties along with southern Galicia). Work continued on Upper Hungary under Joseph II, as Colonel Neu supervised the survey $(1782,1783,1784)$. The rest of Hungary followed between 1782-1785 under the direction of Colonel Baron Motzel and Colonel Neu (Nischer-Falkenhof 83-5).

[6] The Hungarian nobility possessed a strong sense of the rights guaranteed them by the Hungarian constitution. Their collective notion of themselves in this period is known as "rendi nacionalizmus" (feudal nationalism). In the early nineteenth century, Hungarian feudal nationalism merged with aspects of liberal nationalism, such as the demand to expand the scope of the Magyar language in the Hungarian Kingdom. National identity in the context of the paper implies both Görög's rendi nacionalizmus, his sense of himself as a nobleman, and his liberal nationalism, including a sense of himself as a Magyar.

[7] Demeter Görög was born in Hajdúdorog to Sára Tóth and Demeter Görög. He completed four years of Gymnasium schooling in Debrecen and the remaining three years in Ungvár. From 1779 he studied humanities and law in Nagyvárad, and then went on to continue law studies in Vienna. He is most well-known for his work as a tutor to aristocratic young men in the highest circles. His charges included Count László Kollonics, Prince Pál Eszterházy, from 1803 the Archduke Josef, son of Emperor Francis, and Archduke Francis Charles.

[8] Another institute capable of a similar level of map production did not come into existence for another seventy years. 
[9] Görög's appointment to serve as governor at the imperial court led to the censorship of the MagyarHirmondó (Magyar News).

[10] Hadi és más nevezetes történetek (Military and Other Stories of Note) (1789): first part, near the beginning.

[11] Magyar Hirmondó (Magyar News) 24 (March 26 1799): 385.

[12] The engraving engineers were called Winter and Agneton (Márton 24).

[13] Mátyás Bél's books on geography included some of Mikoviny's maps: Volume One contained Pozsony county (1735), Volume Two Turóc, Zólyom and Liptó (1736), Volume Three Pest, Pilis and Solt (1738), Volume Four Nógrád , Hont, Bars, and Nyitra (1742), while Volume Five contained a map of Moson county (1745). See Bendefy 29.

[14] The Hajduks were originally herdsmen who were driven from their homes during the Turkish wars and lived as soldiers in the sixteenth and seventeenth centuries. As Görög originated from the region, the author argues that some of this independent spirit genetically survived in him. For more information on the Hajduks in Hungary, see Dávid 5-42. Those interested in Hajduk activities in what are today Balkan lands and Romania, see Ionescu-Niscov 122-5.

[15] Mapmakers chose a broad palette of colors to depict the different kingdoms, special districts and regions of the Kingdom of Hungary. I am not aware of the reasons behind their color choices, although these decisions may have possessed special significance.

[16] Transylvania became detached from Hungary during the expansion of the Ottoman Empire into Europe. By 1570 it had become a separate principality with a prince who owed his sovereignty to the Sultan (Lendvai 110 and 113). The dispute between the Hungarian Estates and the king over Transylvania dates back to this time.

[17] The majority of the Hungarian population was not literate at the time. Even the most privileged group in society, the nobility, had many members who resembled the peasantry in their level of learning. These nobles constituted the kisnemesség, or lesser nobility. By the end of the nineteenth century, approximately 400000 people belonged to this group. These nobles would have generally spoken German and Latin at a lower level than their middle noble and magnate noble counterparts. See Gergely 92-4.

[18] Ferenc Deak (1803-1876) was one of the most important politicians in the reform period. He is best known for a later achievement, namely his role in helping create the Austro-Hungarian compromise of 1867 through his passive resistance tactics in parliament in the early 1860s (Lendvai 270-1).

[19] For the concept of Magyar liberal-nationalism, see Gergely 206-7.

[20] For example, the Post Atlas von Ungarn und damit verwandten Laendern mit beiden Galizien. In zehen Blättern (Postal Atlas of Hungary and the Lands Connected with It along with the Two Galizias. In Ten Plates). These maps showed postal maps of Hungary on first one, then the other side of the Danube, and on both sides of the Tisza river as well.

[21] To give one instance, Karacs engraved but did not produce (Karacs, 1798). 
[22] Kultsár was an editor, patron of writers and had a literary salon in the reform period. He began Hazai tudósitások (Domestic Reports) in 1806. As was the case with Görög's paper, Hadi és más nevezetes történetek (Military and Other Stories of Note), this one too was backed financially by Counts Ferenc Széchenyi, György Festetics and Sámuel Teleki. Kultsár died in 1828, and the paper became more conservative as the reform period progressed. By 1840 it changed its name to Nemzeti Ujság (National News and came under the influence of the Catholic church. See Kókay 181 and 253-4.

\section{WORKS CITED}

Atlas der neuen Geographie zum Gebrauche der Schulen in den österreichisch kaiserl. königl.deutschen Erbstaaten (Atlas Depicting New Geography for the Use of Schools in the Imperal, Royal German Hereditary States). Vienna: K.k. Schulbücher, 1813. Országos Széchenyi Könyvtár Térképtár (Hereafter OSzK TK) TA 6133.

Barrow, Ian J. Making History, Drawing Territory: British Mapping in India c1756-1905. New Delhi: Oxford University Press, 2003.

Bendefy, László. Mikoviny Sámuel megyei térképei különös tekintettel az akadémiai könyvtár kézirattárának Mikoviny térképeire. Második kötet (The County Maps of Sámuel Mikoviny, with Particular Attention to the Academic Library's Manuscript Department Mikoviny Maps. Second Volume). Budapest: Magyar Akadémiai Könyvtár, 1976.

Bérenger, Jean. A History of the Habsburg Empire 1700-1918. London: Longman, 1997.

Csaplovics, Johann von. Gemälde von Ungarn (Portrait of Hungary). Pest: Hartleben, 1829.

Danku, Gyuri. "Vasvári Pál földrajzi atlasza" ("The Geographic Atlas of Pál Vasvári"). Unpublished essay, Map Department, National Széchenyi Library, Budapest.

Dávid, Zoltán. “A Hajduk letelepitése." (“The Hajduk Settlements"). Történeti Statisztikai Tanulmányok (Historical Statistical Studies) 1 (1975): 5-42.

Delano Smith, Catherine. "Why Theory in the History of Cartography?" Imago Mundi 48 (1996): 198-203.

Dickson, P.G.M. "Joseph II's Hungarian Land Survey." English Historical Review 106, 420 (July 1991): 611-634.

Ecsedi, István. Karacs Ferenc Térképmetszó élete és müvei (1770-1838) (Ferenc Karacs: The Map Engraver's Life and Works (1770-1838)). Debrecen: Szent Király Város Press, 1958.

Edney, Matthew H. "Theory and the History of Cartography." Imago Mundi 48 (1996): 185-191.

"Erbkaisertum Oesterreich" ("Hereditary Imperial Lands of Austria"). Atlas der neuen Geographie. Map. Vienna: K.k. Schulbücher, 1813: plate 4. OSzK TK TA 6133.

Erős, Gábor, Józsep Pap, and Dávid Pethes. Oskolai magyar új atlás kidolgozta és a' mennyire lehetett a' nemzet nyelvéhez alkalmaztatta Prof. tt. Budai Ésaiás Ur Metszették és nyomtatták a' Debreczeni Ref. Collegium Nagy Érdemüelójáróinak, és tt. Prédikátorok Endrédi József és Szoboszlai Sámuel Uraknak segitségével Debreczeni 
togatus Deákok: Erốs Gábor, Pap Józsefés Pethes Dávid Debreczenbenn. (New Hungarian School Atlas Produced and as Much as Possible Adjusted to the National Language by Respected Prof. Ésaiás Budai, Engraved and Printed for the Worthy Lower Students of the Debrecen Cavinist Collegium with the Help of Well-Known Pastors József Endrédi and Sámuel Szoboszlai by the Upper Level Students Gábor Erós, Józsep Pap and Dávid Pethes in Debrecen). Debrecen: Calvinist Collegium, 1804. OSzK TK TA 3918.

Evans, R.J.W. "Essay and Reflection: Frontiers and National Identities in Central Europe." The International History Review XIV, 3 (August 1992): 480-502.

Fried, Franz. Atlas der neuesten Geographie für Jedermann und jede Schulanstalt (Atlas Depicting the most recent Geography, for Every Person and All School Establishments). Vienna: Artaria u Comp., 1834. OSzK TK TA 4684.

. "Karte von Tirol, Steyermark, Illyrien" ("Map of Tirol, Styria, and Illyria"). Atlas der neuesten Geographie. Map. Vienna: Artaria u Comp.,1834: plate 10. OSzK TK TA 4684.

.Karte von Boehmen und der Markgrafschaft Maehren mit dem Antheile des Österreichischen herzogthumes Schliesen" ("Map of Bohemia and the Margravate of Moravia with Portions of the Austrian Duchy of Schliesen"). Atlas der neuesten Geographie). Map. Vienna: Artaria u Comp., 1834: plate 11. OSzK TK TA 4684.

."Karte von Ungarn und Galizien" ("Map of Hungary and Galicia"). Atlas der neuesten Geographie. Map. Vienna: Artaria u Comp., 1834: plate 12 OSzK TK TA 4684.

Für, Lajos. Magyar Sors a Kárpát-Medencében, Népesedésünk évszázadai 896-2000. (Hungarian Fate in the Carpathian Basin, Centuries of the Growth of Our Population, 896-2000). Budapest: Kairosz, 2001.

Gergely, András, ed. Magyarország története a 19. században (The History of Hungary in the $19^{\text {th }}$ Century). Budapest: Osiris, 2005.

Görög, Demeter. Magyar Átlás, az az Magyar, Horvát és Tót országok vármegyéji szabad kerületei és a' határ-ốrzókatonaság vidékinek közönséges és különös tábláji (Magyar Atlas, Including General and Special Plates of the Hungarian, Croatian and Slavonian Countries' Castle Districts, Free Regions, and the Military Border Districts). Vienna: Demeter Görög and József Márton, 1802-1811. OSzK TK TA 4677.

- Mutatótábla vagyis Repertórium A' Magyar Átlásnak LIX mappáiban találtató minden magyarországi, horvátországi és slavóniai városok, mezóvárosok, helységek, nevezetesebb puszták, folyóvizek, és hegyek neveit, abécze rendben, magyar, deák, német, tót és oláh nyelveken, $a^{\prime}$ fekvéseket jelzó vármegye nevével és a' járás számával együtt (Table or Repertory Showing Names in Alphabetical Order of All Hungarian, Croatian, and Slavonian Cities, Agricultural Cities, Places, Notable Prairies, Rivers and Elevations in Hungarian, Latin, German, Slav and Romanian Languages, With the Name of the Castle County in Question and Its District Number). Vienna: József Márton, 1811. OSzK TK T1 516. Hadi és más nevezetes történetek (Military and Other Stories of Note) (1789).

Hannerz, Ulf. “The World in Creolisation.” Africa 574 (1987): 546-59. 
Harley, J.B. "Meaning and Ambiguity in Tutor Cartography." English Map-Making 1500-1650: Historical Essays. Ed. Sarah Tyacke. London: British Library, 1983. 22-45.

. "Deconstructing the Map." Cartographica 262 (1989): 1-20.

. "Maps, Knowledge and Power." The Iconography of Landscapes: Essays on the Symbolic Representation, Design and Use of Past Environments. Eds. Denis Cosgrove and Stephen Daniels. Cambridge: Cambridge University Press, 1988. 277-312.

Harley, J.B., and D. Woodward eds. The History of Cartography Volume One: Cartography in Prehistoric, Ancient and Medieval Europe and the Mediterranean. Chicago: University of Chicago Press, 1987.

eds. The History of Cartography: Cartography in the Traditional Islamic and South Asian Societies, Vol. Two Book One. Chicago: University of Chicago Press, 1992.

eds. The History of Cartography: Cartography in the Traditional East and Southeast Asian Societies, Vol. Two Book Two. Chicago: University of Chicago Press, 1994.

Harley, J.B., and K. Zandvliet. "Art, Science and Power in Sixteenth-Century Dutch Cartography." Cartographica 292 (1992): 10-19.

Haselsteiner, Horst. Joseph II und die Komitate Ungarns: Herrscherrecht und ständischer Konstitutionalismus (Joseph II and The Hungarian Counties: The Right of the Sovereign and Constitutionalism of the Feudal Orders). Vienna: H. Böhlaus, 1983.

Horvath, J. Eugene. A Canadian Collection of Hungarica, Maps and City Views 1493-1817. Vancouver: Eugene Horvath, 2001.

Ionescu-Niscov, Traian.“Sur La Toponymie Des 'Haidouks' Dans Les Pays Roumains: Quelques Sommaires Considerations Sur La Vie De Haidouk Dans Les Pays Roumains" ("On the toponymy of haiduks in the Romanian territories: some summary considerations on the life of the haiduks in the Romanian areas"). Etudes Balkaniques 253 (1989): 122-5.

Jacob, Christine. "Toward a Cultural History of Cartography." Imago Mundi 48 (1996): 191-198.

Jankó, Annamaria. "A második katonai felmérés" ("The Second Military Survey"). Hadtörténelmi Közlemények (Military Communiqués) 114, 1 (2001): 103-29.

Kálvinfalvai, Béla. Karacs Ferenc, térképkészitörézmetszô müvész (1770-1838) (Ferenc Karacs, Map Maker-Engraver Artist (1770-1838)). Debrecen: Szabadság Nyomda, 1958.

Karacs, Ferenc. Erdély ország közönséges földképe mellyet az alsóbb Oskolabeli Ifjak számára metszett és kiadott Karacs Ferencz (General Map of the Country of Transylvania, which was Engraved and Published for the Benefit of School Age Youth by Ferencz Karacs). Map. Pest: 1834.OSzK TK TR 35. . Magyar országnak földképe melly az eddig készültt mappákból lehetóképen meg jobbitva a' köz haszonra ki bocsáttatott Pesten (Geographical Picture of Hungary Improved as Best Could Be from Maps That Have Already Appeared for the Benefit of General Use Distributed in Pest). Map. Pest: András Vályi, 1798. OSzK TK TR 7111. 
Magyar Országnak és a' hozzá kaptsoltatott Horváth és Tót országoknak, 's határórzókatonai vidékeknek, nem különben az Erdélyi Nagy Fejedelemségnek vármegyékre és szabad kerületekre ösztatott 's a' leg jobb mappák szerént készittetett közönséges táblája (General Map of Hungary and the Countries of Croatia and Slavonia Added to it, and the Military Districts, not Excluding the Great Principality of Transylvania, Divided into Castle Counties and Free Districts and Made According to the Best Maps). Map. Pest: Ferenc Karacs, 1813. OSzK TK TM 6166.

. Európa Magyar Atlása a legujabb politikai, geographiai és statistikai hiteles adatok szerént a' polgári kormányzók, katona tisztek, újságolvasók, kereskedók, utazók és tanulók köz hasonvételére nemzeti magyar nyelven 21 táblában (European Hungarian Atlas in 21 Tables, According to the Newest Political, Geographical and Statistical Facts for the General Use of Civil Governors, Officers, Newspaper Readers, Business People, Travellers, and Students in the National Magyar Language). Pest: Ferenc Karacs and Baumann printers, 1834-1838. OSzK TK TA 4458.

Karte von dem Königreiche Ungarn mit den königreichen Kroatien und Sklavonien und dem Grossfürstenthum Siebenbürgen (Map of the Kingdom of Hungary with the Kingdoms of Croatia and Slavonia and the Great Principality of Transylvania). Map. Pest: Industrie Comptoir, 1814. OSzK TK TR 1515.

Kókay, György., ed. A magyar sajtó története I: 1705-1848 (The History of the Hungarian Press I: 1705-1848). Budapest: Akadémiai Kiadó, 1979.

. A magyar sajtó története I: 1705-1848 (The History of the Hungarian Press I: 1705-1848). 1979. 16 Nov. 2007 <http://mek.oszk.hu/04700/04727/ html/136.html.>.

Konrad, Adolph. Allgemeiner Hand Atlas zum Gebrauche für Studierende Kaufleute und Zeitungsleser in 25 General- und Special Karten alle nach den politischen Verhältnissen des Jahrs 1812 berichtigt (General Hand Atlas for the use of Business People in Training and Newspaper Readers in 25 General and Special Maps all Corresponding to the Political Situation of the Year 1812). Pest-Vienna: Tranquillo Mollo, 1812. OSzK TK TA 1779.

."Charte der Österreichischen Monarchie" ("Map of the Austrian Monarchy"). Allgemeiner Hand Atlas. Map: 16. OSzK TK TA 1779.

."Charte von Ungarn und Siebenbürgen" ("Map of Hungary and Transylvania"). Allgemeiner Hand Atlas. Map:17. OSzK TK TA 1779.

Korabinszky, János Mátyás. Atlas Regni Hungariae portatilis: Neue und vollständige Darstellung des Königreichs Ungarn auf LX Tafeln im Taschenformat. Ein geographisches Noth und Hülfsbüchlein fürs gemeine Leben (Portable Atlas of the Kingdom of Hungary: New and Complete Representation of the Kingdom of Hungary on LX Plates in Pocket Format. A Geographical Necessity and Reference Booklet for Everyday Life). Map. Vienna: Schaumberg and Compagnie, 1804. OSzK, TK TA 1022.

Korabinszky, Johann Matthias. Geographisch-historisches und Produkten Lexicon von Ungarn in welchem die vorzüglichsten Oerter des Landes in alphabetischer Ordnung angegeben, ihre Lage Bestimmt, und mit kurzem Nachrichten, die im gesellschaftlichen Umgange angenehm und nützlich sind (Geographical and Historical Product Lexicon of Hungary in which the most excellent Places of the Country are Given in Alphabetical Order, According to their Position, and with Short Descriptions which 
are Pleasant and Useful in Social Intercourse). Pressburg: Weber and Korabinszky, 1786.

Lendvai, Paul. The Hungarians: A Thousand Years of Victory in Defeat. Princeton: Princeton University Press, 2003.

Magyar Hirmondó (Magyar News) 24 (March 26 1799).

Mappa novissima regnorum Hungariae, Croatiae, Sclavoniae nec non Magni Principatus Transylvanie (New Map of the Kingdom of Hungary, Croatia, Slavonia, but not of the Great Principality of Transylvania). Map. Vienna: Artaria et Comp., 1801. OSzK TK TM 23076.

Márton, József. Görög Demeter ts.k.udvari föneveló, aranykultsos és udvari tanátsos hazánkfiának, sz. István apost. magyar király rendje közép keresztes életirása és a magyar literatura elómozditása által, valamint a nevelés pályájan szerzett érdemei (The Biography of Demeter Görög, Imperial and Royal Governor, Holder of the Golden Key and Court Counsellor, Compatriot, Bearer of the Middle Cross of the Apostolic Saint István Royal Order, including His Received Awards in the Field of Education and for his Progression of Hungarian Literature). Vienna, 1834.

Mikó, Mrs. Pál. "Görög Demeter a császár udvarában” ("Demeter Görög at the Emperor's Court"). Magyar Könyvszemle (Hungarian Book Review) 102 (1986): 91-8.

Molnár, József. Görög Demeter (Demeter Görög). Debrecen: Városi Nyomda, 1938.

Nagy, Júlia. "A Magyar Átlás" ("The Hungarian Atlas"). Földrajzi Értesitố (Geographical Report) XXVI 3-4 (1977a).

. "Görög Demeter, Kerekes Sámuel és Márton József, a XVIII századi magyar térképészet kiemelkedőmüvelői" ("Demeter Görög, Sámuel Kerekes and József Márton: Exceptional Practitioners of XVIII Century Hungarian Cartography") Földrajzi Értesitó (Geographical Report) XXVI 2 (1977b): 211-12.

Nischer-Falkenhof, Ernst von. "The Survey by the Austrian General Staff under the Empress Maria Theresa and the Emperor Joseph II, and the Subsequent Initial Surveys of Neighbouring Territories During the Years 1749-1854." Imago Mundi Vol.2 (1937): 83-5.

Paget, John. Hungary and Transylvania with Remarks on their Condition, Social, Political and Economical. London: John Murray, 1839.

Papp-Váry, Arpád. Magyarország története térképeken (The History of Hungary in Maps). Budapest: Kossuth Kiadó, 2002.

Popova, Irina. "Representing National Territory: Cartography and Nationalism in Hungary, 1700-1848." Creating the Other: Ethnic Conflict and Nationalism in Habsburg Central Europe. Ed. Nancy M. Wingfield. New York: Berghahn, 2003. 19-38.

Pratt, Mary Louise. Imperial Eyes: Travel Writing and Transculturation. London: Routledge, 1992.

Schedius, Lajos, and Sámuel Blaschnek. Magyar Ország, Horvát, Tót, Dalmát, és Erdély Országok $a^{\prime}$ tenger mellék' és a' végóri vidékek' közönséges posták és útak' földabrosza az Austriai tsaszárság' határos tartomány részeivel együtt, a' leg jobb kútfökból meritett, leg biztosabb elóadások szerént (Map of the Countries of Hungary, Croatia, Slavonia, Dalmatia, and Transylvania, the Coastal Region, the Military Districts, General Postal Stations and Roads along with the Border Regions of the 
Austrian Empire, using the best Sources and Means of Presentation). Map. Pest: Lajos Schedius and Sámuel Blaschnek, 1833-1836. OSzK TK TR 2846.

Schedius, Ludwig. Karte des Königreichs Ungarn seiner Nebenländer und Siebenbürgen's Nach den besten Quellen herausgegeben von Ludwig von Schedius (Map of the Kingdom of Hungary, Its Neighbouring Lands and Those of Transylvania According to the Best Sources, Produced by Ludwig von Schedius). Map. Pest: Eggenberger u. Heckenast, 1838. OSzK TK TM 5771.

Swatridge, Colin. A Country Full of Aliens: A Briton in Hungary. Budapest: Corvina, 2005.

Szántai, Lajos. Atlas Hungaricus. Magyarország nyomtatott térképei 1528-1850 Kötet kettó (AtlasHungaricus. The Printed Maps of Hungary, 1528-1850 Volume Two). Budapest: Akadémiai kiadó, 1996.

Szász, Zoltán, ed. Erdély története, harmadik kötet 1830-tól napjainkig (The History of Transylvania, Third Volume, From 1830 until Present Day). Budapest: Akadémiai Kiadó, 1987.

Thody, Philip. Roland Barthes: A Conservative Estimate. Chicago: University of Chicago Press, 1983.

"Ungarn samt den Vereinigten Ländern und Siebenbürgen" ("Hungary Together with the United Lands and Transylvania"). Atlas der neuen Geographie. Map. Vienna: K.k. Schulbücher, 1813: plate 9-10. OSzK TK TA 6133.

Vann, James. "Mapping under the Austrian Habsburgs." Monarchs, Ministers and Maps, The Emergence of Cartography as a Tool of Government in Early Modern Europe. Ed. David Buisseret. Chicago: University of Chicago Press, 1992. 153-67.

Wintle, Michael. "Renaissance maps and the construction of the idea of Europe." Journal of Historical Geography 25, 2 (1999): 137-65.

Wolff, Larry. Inventing Eastern Europe: The Map of Civilisation on the Mind of the Enlightenment. Stanford: Stanford University Press, 1994.

Woodward, David and Lewis G. Malcom eds. The History of Cartography: Cartography in the Traditional African, American, Arctic, Australian and Pacific Societies. Chicago: University of Chicago Press, 1998. 
ILLUSTRATIONS

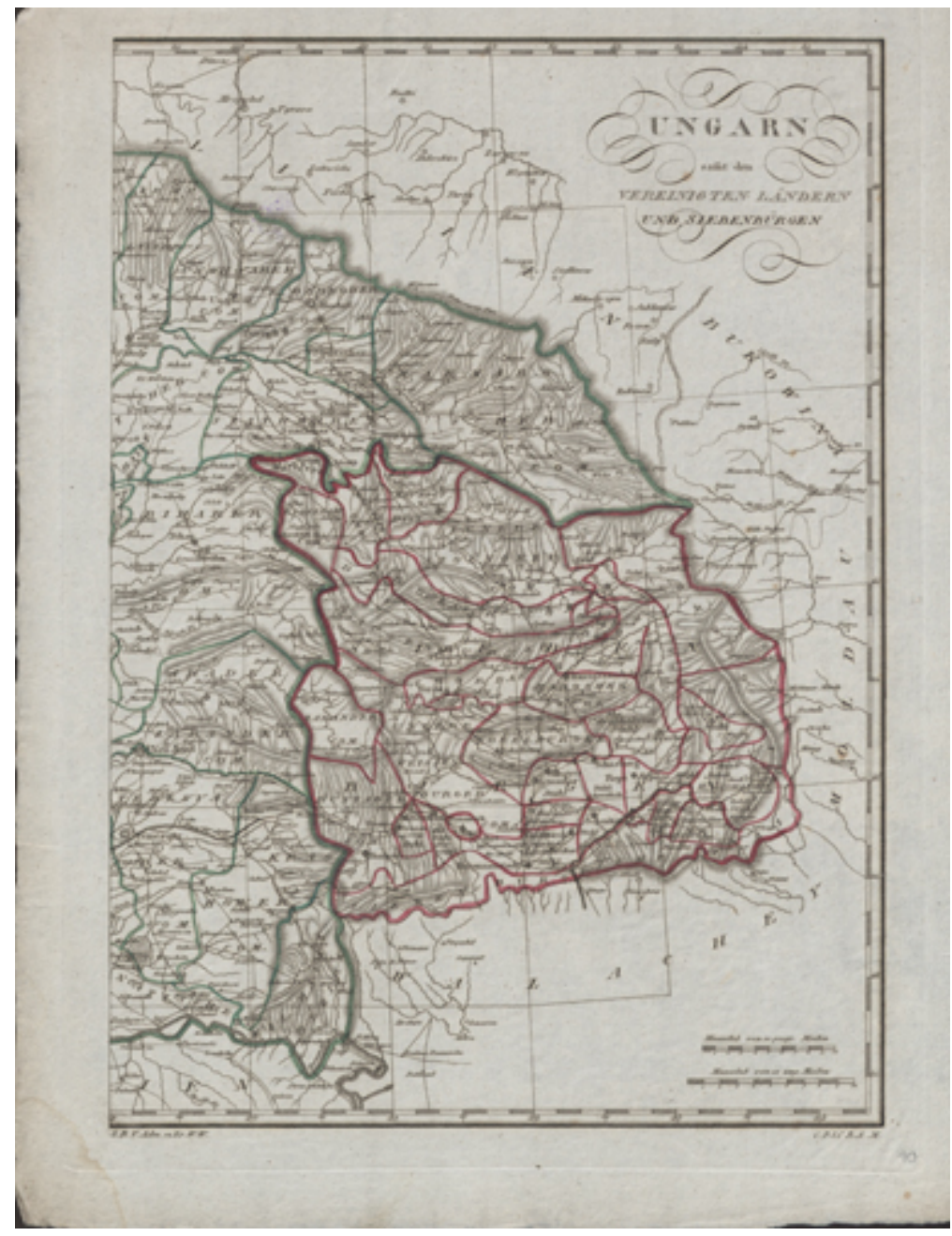

Illustration 1 


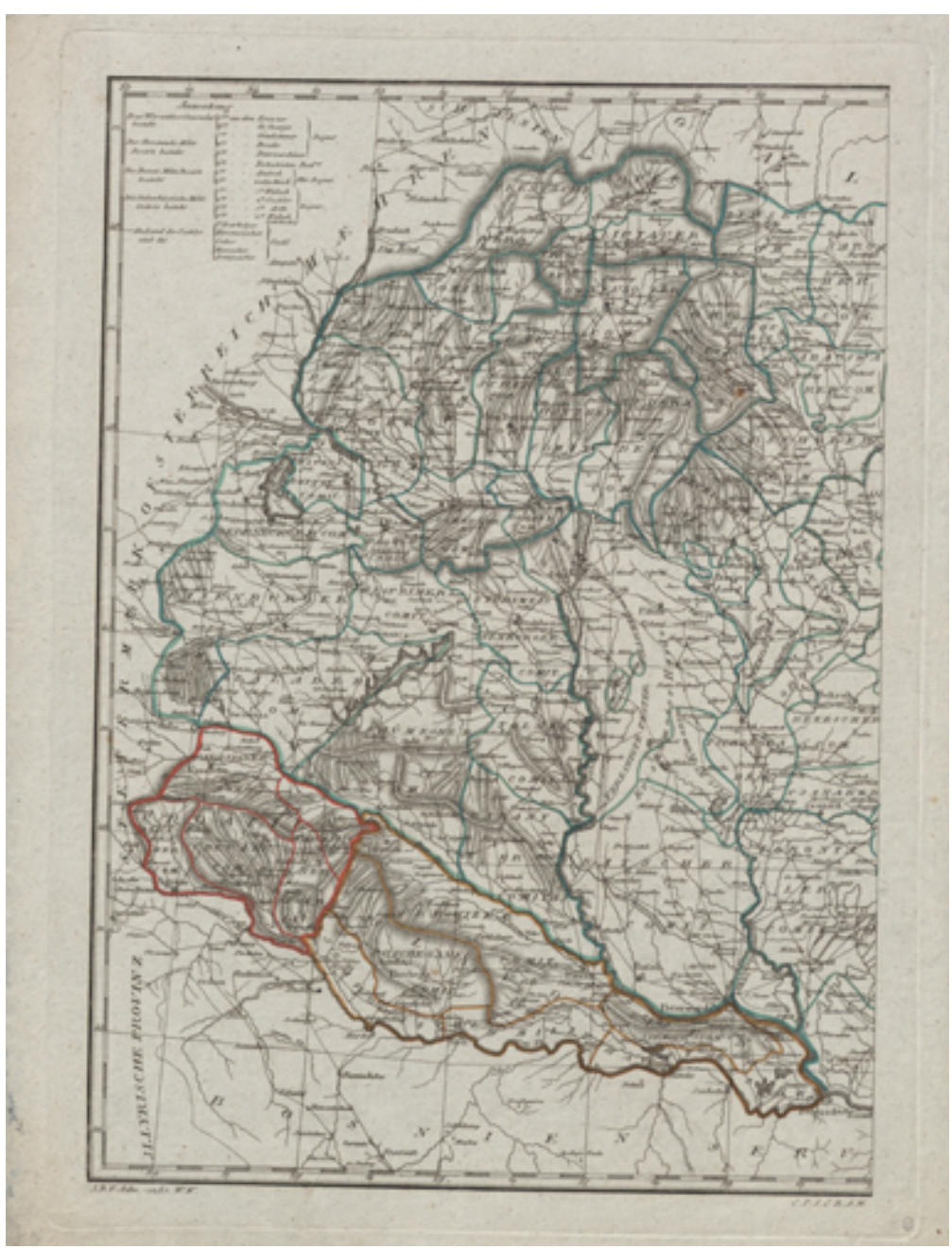

Illustration 2 


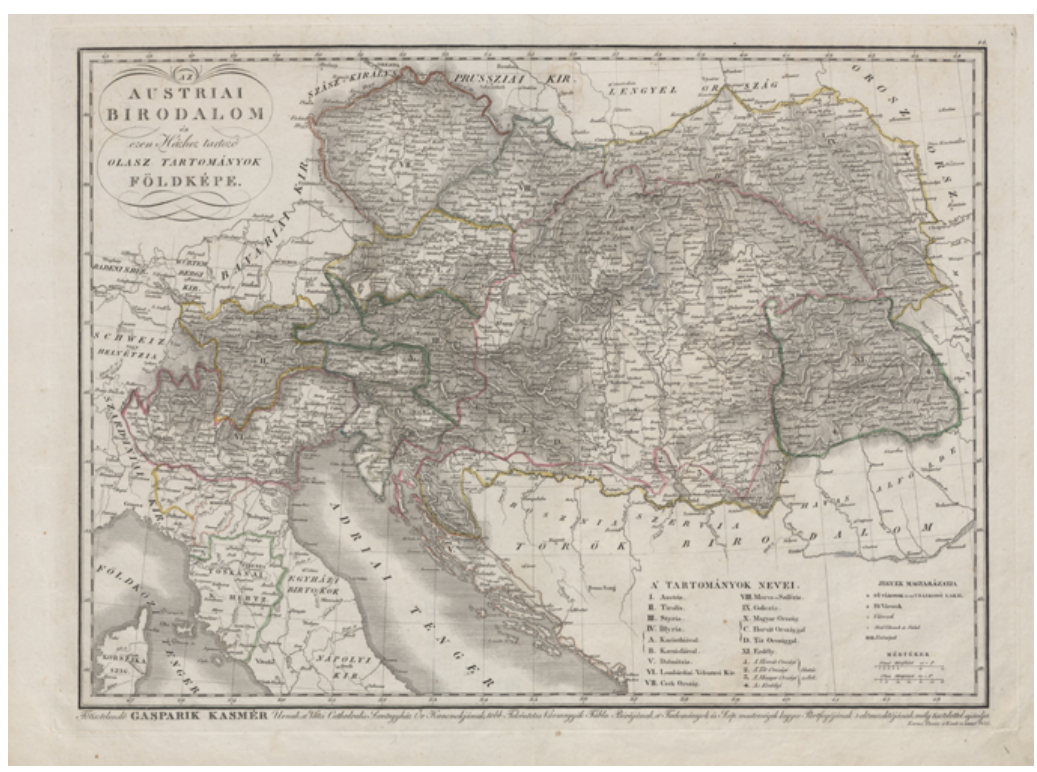

Illustration 3 


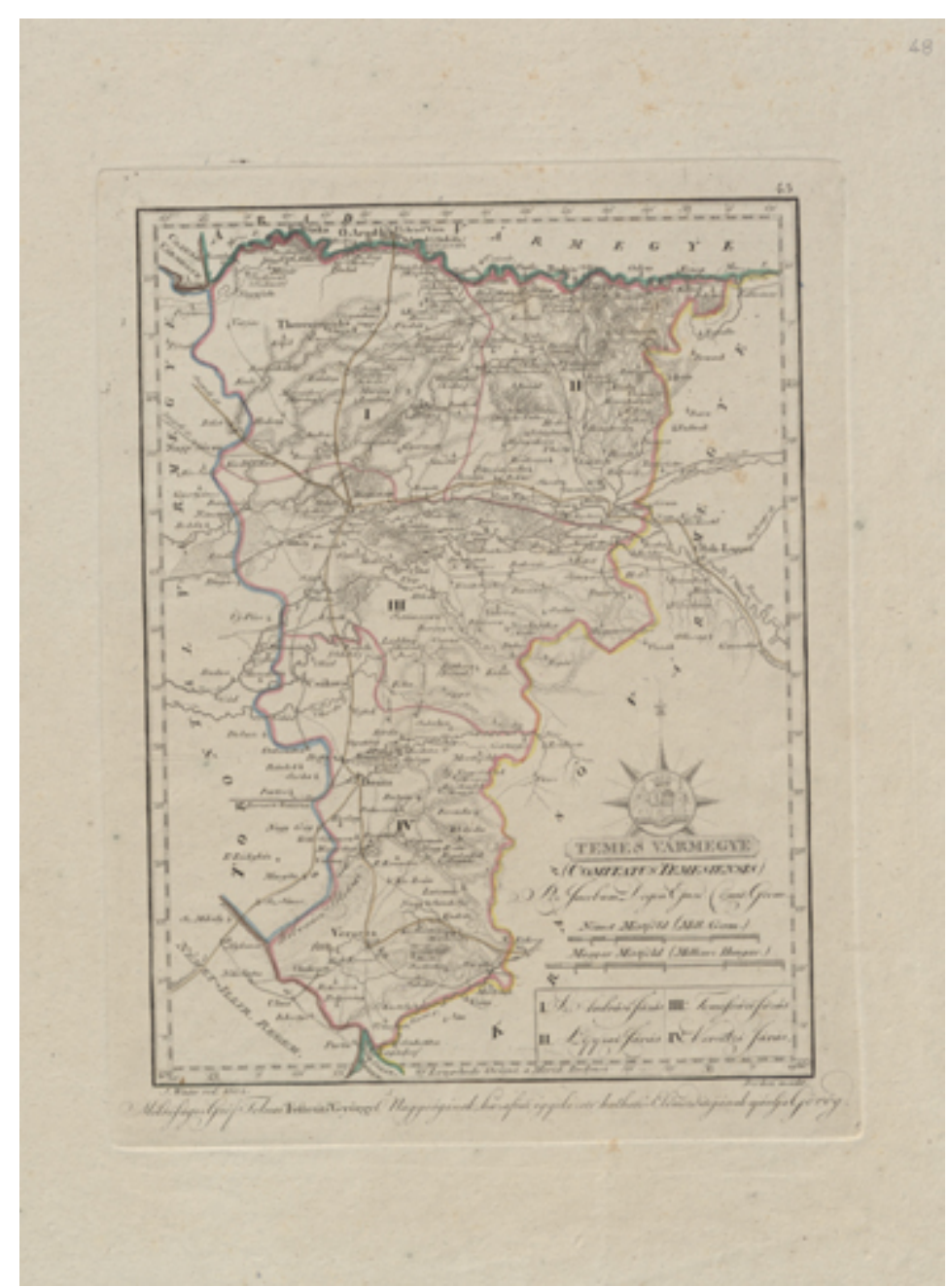

Illustration 4 